Informasi - ISSN (p) 0126-o650; ISSN (e) 2502-3837

Vol. 49, No. 2 (2019), pp. 145-156 doi: http://doi.org/10.21831/informasi.v49i2. 27827

\title{
DIGITAL ECONOMIC LITERACY MICRO, SMALL AND MEDIUM ENTERPRISES (SMES) GO ONLINE
}

\author{
Yosi Erlanitasari \\ nikasaja@gmail.com \\ Andre Rahmanto \\ andreyuda@gmail.com \\ Mahendra Wijaya \\ mahendrawijaya@staff.uns.ac.id \\ Master Program Of Communication Science, Faculty of Social and Political Sciences, \\ Universitas Sebelas Maret, Surakarta, Indonesia
}

\begin{abstract}
Micro, Small and Medium Enterprises (SMEs) have a very vital role in the development and economic growth. In the history of the Indonesian nation's economy, SMEs as a support of the national economy. To make SMEs rise in class, a strategy is needed where one of them is the use of digital economic literacy. Development of digitalbased SMEs needs to be done digital literacy so that when SMEs are able to utilize digital technology it will increase revenues by up to $80 \%$. At present, the number of SMEs in Indonesia reaches 62,922,617 units of which the highest number is in the Micro Scale 62,106,900 business units (98.70\%) with Small Business 757,090 units (1.20\%), and Medium Enterprises 58,627 units (o, o9\%). This research was aimed at toanalyze the Go Online SMEs Movement program launched by the government from 2017 until now, even for the future this program will be launched. The research was conducted with a qualitative content analysis method in which primary data online portal research through the Google search engine. Whereas secondary data were obtained from government publications about the Go Online SMEs Movement program. Research shows that only $36 \%$ of SMEs in Indonesia is still struggling with conventional marketing. Meanwhile, 37\% of SMEs only have basic online marketing capacity such as computer and broadband access. The remaining 18\% of SMEs have medium online capacity because they can use websites and social media. Only 9\% have digital marketing capacity that can be categorized as sophisticated. The study recommended the importance of the government conducting intensive socialization of the Go Online SMEs Movement. In fact, it must also be at the level of assistance for SMEs. SMEs must be the main players in the development of the digital economy in Indonesia. Collaboration between government and e-commerce is carried out continuously to make Indonesia the Digital Energy of Asia by 2020.
\end{abstract}

Usaha Mikro, Kecil, dan Menengah (UMKM) memiliki peran yang sangat vital di dalam pembangunan dan pertumbuhan ekonomi. Dalam sejarah perekonomian bangsa Indonesia, UMKM sebagai penopang perekonomian nasional. Untuk 
menjadikan UMKM naik kelas, dibutuhkan strategi dimana salah satunya adalah penggunaan literasi digital ekonomi. Pengembangan UMKM berbasis digital perlu dilakukan literasi digital sehingga ketika UMKM mampu memanfaatkan teknologi digital akan meningkatkan penerimaan hingga 80\%. Saat ini, jumlah UMKM di Indonesia mencapai 62.922.617 unit dimana dari jumlah tersebut terbanyak di Skala Mikro 62.106.90o unit usaha (98,70\%) dengan Usaha Kecil 757.09o unit (1,20\%), dan Usaha Menengah 58.627 unit (o,o9\%). Penelitian ini bertujuan untuk menganisis program Gerakan UMKM Go Online yang diluncurkan pemerintah sejak tahun 2017 sampai dengan sekarang, bahkan untuk masa yang akan datang program ini akan terus diluncurkan. Penelitian dilaksanakan dengan metode analisis isi kualitatif dimana data primer penelitian portal online melalui mesin pencari Google. Sedangkan data sekunder didapat dari publikasi pemerintah mengenai program Gerakan UMKM Go Online. Hasil peneitian menunjukkan hanya 36\% UMKM di Indonesia masih berkutat dengan pemasaran konvensional. Sedangkan, 37\% UMKM hanya memiliki kapasitas pemasaran online yang bersifat mendasar seperti akses komputer dan broadband. Sisanya, sebesar 18\% UMKM memiliki kapasitas online menengah karena dapat menggunakan website dan medsos. Hanya 9\% saja yang memiliki kapasitas pemasaran digital yang bisa dikategorikan canggih. Penelitian merekomendasikan pentingnya pemerintah melakukan sosialisasi secara intensif mengenai Gerakan UMKM Go Online. Bahkan, juga harus pada tataran pendampingan pada pelaku UMKM. UMKM harus menjadi pemain utama dari perkembangan ekonomi digital di Indonesia. Kolaborasi antara pemerintahan dan e-commerce dilakukan secara kontinyu untuk menjadikan Indonesia sebagai Digital Energy of Asia pada 2020.

Keywords: Digital Literacy, SMEs, Digital Economic Literacy, SMEs Go Online

\section{INTRODUCTION}

Micro, Small and Medium enterprises (SMES) as stated in the presidential Decree RI No. 19 of 1998 is the people's economic activities on a small scale that needs to be protected and prevented from unfair competition. In the Business Profile of SMES compiled by the Institute of Development Banking in Indonesia, Bank of Indonesia (BI), Micro, Small and Medium enterprises (SMES) have an important and strategic role in national economic development. In addition to a role in economic growth and employment, SMES also play a role in distributing development results. SMES have also been proven to be not affected by the crisis. When the crisis hit in the period 19971998, only SMES that are able to stand sturdy.

The Data of the Central bureau of Statistics showed, after the economic crisis of 1997-1998 the number of SMES has not diminished, rather increased constantly, even able to absorb the 85 million to 107 million workforce until the year 2012. In that year, the number of entrepreneurs in Indonesia as much as 56.539 .560 unit. Of these, Micro, Small and Medium enterprises (SMES) as much as 56.534 .592 units or $99.99 \%$. The rest, about $0.01 \%$ or 4.968 units is a huge undertaking. These Data prove, SMES is a very potential market for the financial services industry, especially banks to channel financing. Because about $60-70 \%$ of SMES do not yet have access to banking financing. The experience has been aware of the many parties, to give a larger portion of the business scale of micro, small, and medium. The government and the legislature prove his attention towards SMES with the launch of the Law No. 20 Year 2008 on SMES. With the regulations that become the law, the motion of the SMES to be more flexible.

The latest Data, ministry of cooperative and SME (Wartaekonomi.co.id, 2019), the development and progress of SMES as a fighter of the nation's economy, which support the economy of the country is a pride for Indonesia. Currently, the number of SMES reached 62.922.617 unit of which the most at the Micro-Scale 62.106.900 
business unit $(98,70 \%)$ with Small Business 757.090 unit (1.20 percent), and Mediumsized Businesses 58.627 units (o,09\%).

In a global perspective has been recognized that SMES play a role that is very important in the development and economic growth. Similarly in the history of the Indonesian economy all parties acknowledge the existence of SMES as the backbone of the economy national. SMES ride the class has been initiated by the Association of Business Development Services Indonesia (ABDSI) through the movement of one million SMES to a higher Class. The approach of the movement to spur the competitiveness of SMES with the theme "SMES Grade" rolling since the end of 2013 through a variety of meetings, discussions, a workshop was conducted to finalize the concept and embrace the many parties that are willing to support the idea. The definition of SMES rose this class is simple if the business is growing, productivity increased, and competitiveness improved, so that all micro businesses have the same potential to up grade to a higher category. Micro can be a small business, small businesses can become medium-sized businesses, medium sized businesses could rise to be a large undertaking. A variety of strategic roles owned by the SMES sector, however this sector also faced various problems. Obstacles and problems, among others, from the aspect of capital, the ability of business management, and the quality of human resources managers. Constraints and problems of small and informal businesses also caused because of the difficulty of access to information and productive resources such as capital and technology, which resulted into the limited ability of small businesses to thrive (Supriyanto, 2006).

To help SMES ride class is not easy, where one of its parameters is the use of internet-based technologies/digital. Internet users, (Wicaksono, 2018), internet users in Indonesia recorded an increase in year 2018 ago. Based on the results of a study Polling Indonesia which cooperate with the "Asosiasi Penyelenggara Jasa Internet Indonesia (APJII)", the number of internet users in Indonesia grew 10,12\%. According to APJII, the survey involved of 5,900 sampled with a margin of error of $1.28 \%$. The result, according to Henri, from a total population of 264 million inhabitants of Indonesia, there are as many as 171,17 million, or about 64.8 percent who are already connected to the internet. This figure increased from the year 2017 when the numbers internet penetration in Indonesia was recorded as $54,86 \%$.

Although the number of internet users in Indonesia is very large, but the level of literacy of the digital is called is still low, including among SMES. Creative Economy agency (Bekraf) rate of digital media is very instrumental in all aspects of community life now, one of them in the trade sector. The level of inclusion of digital Indonesia called good because social media users are very much and the level of use of the internet also reached $60 \%$ of the population. However, it is inversely proportional to the level of literacy of the digital. Businesses with digital literacy that will better understand the ways to market the product with the appropriate target market and not trick consumers related to the goods traded, either intentionally or not. In other words, SMES should be encouraged so that digital literacy and master the market place, (Bisnis. com, 2017).

According to Jordana \& Suwarto (2017), digital literacy is not just the range of ability of using new technologies, learning to use a new device, or even applying the devices and technologies into the learning process. On the contrary, digital literacy is the ability of the results of the high adaptability that allows people to harness technical skills and navigate the diverse information that exists in the internet network. Technical ability in accessing technology now can be changed later in the day, but digital literacy forms a person to be ready in the present and the foreseeable future, any form of technology that will exist later. Like other terminology in social science, digital literacy has a different meaning for different people. Alamsyah \& Purnama (2017) found a total of 34 terms that had used to describe 
the digital technology related skills and competences. Digital literacy is prerequisite for people to participate in the Information Age or the Internet Age. In this era, advances in ICT has changed the way of people to produce, distribute, consume and reproduce information. ICT also creates virtual work, virtual environment, and virtual roles that affect the lifestyle of modern peoples (Alamsyah \& Purnama, 2017)). ICT make long distances, and various social barrierseconomic-culturalpolitics becomes not fade due to its ability to connect people from the diverse world. This development gave birth to a new generation of mankind, namely digital native (someone who was born, grew up in the era of digital technology, including computers, mobile phones, video games, connect socially with others through text messaging and various social networks, (Alamsyah \& Purnama, 2017).

While Wicaksono (2018), it cannot be denied that the Indonesian state does have a potential market large enough for a digital business where factors related to the demographic structure that reaches 260 million inhabitants and the most populated a young age. Other factors, the penetration of internet users also has reached $60 \%$ of the total population overall. Reflecting these conditions it is time businesses, Small Businesses Micro and Medium enterprises (SMES) by utilizing digital technology as part of the activities of their businesses. Very visible from the activity of transaction of electronic money showed an increase significantly.

In addition, the research institute Deloitte Access Economics 2015 (Wicaksono, 2018) reveal that when SMES are able to utilize the digital technology will improve their acceptance reaches $80 \%$. Then, for the national economy when SMES go online is potentially accounted for a growth of $2 \%$ in the year 2025 . The distribution chain is relatively long to be one of the factors of the soaring selling price in the market, through digital SMES can market the product more efficiently with more competitive price. The Program digital literacy must be continued to be pursued by the government. Because most of the SMES not only dominated the population of the age of young (19-34 years old) who incidentally have the absorption technology is better. But so far, the programs directed to strengthen the ability of businesses how to leverage digital technologies in business activities is needed. Considering that SMEs are the driving force of the economy and national development, it is necessary to have a strategy to empower the sector. The SMEs sector empowerment policy is directed at supporting efforts to reduce poverty and inequality, create employment opportunities and increase exports, (Hafiluddin, Suryadi, \& Saleh, 2014). Likewise research conducted by Supriyanto (2006), poverty alleviation by developing SMEs has quite good potential. The SMEs sector has a large contribution to employment, which absorbs more than $99.45 \%$ of the workforce. Nevertheless its contribution to GDP is still around 30\%. Efforts to advancing the SMEs sector will certainly be able to improve the welfare of the workers involved in it. Development of SMEs will be able absorb more labor available so that it can reduce unemployment.

In a number of studies, SMEs empowerment is often linked to poverty alleviation, but it is still rare to highlight the problems faced by SMEs themselves. Hejazziey (2009), the problems that exist in the world of SMEs include: (1) Weaknesses in the field of organization and management. (2) Weaknesses in capital structure and limitations in obtaining access points to capital sources. (3) Weaknesses and gain opportunities (market access) and enlarge market share. (4) Limitations in the weakness of the use of access and mastery of technology, especially applied technology. (5) The low quality of human resources which includes aspects of competence, skills, work ethic, character, awareness of the importance of consistent quality and standardization of products and services, as well as entrepreneurial insights. (6) Limitations on the supply of raw materials starting from the amount 
that can be purchased, standardization of the available quality, and the length of the raw material distribution chain. (7) The partnership system that has been rolled out so far has tended to experience distortion at the implementation level so that it has an impact on the sub-ordination of micro, small and medium business operators compared to their business partners (large businesses).

In order to overcome the problem and make the class go up to SMEs, this research highlights the government's efforts through the "Go Online SMES Movement" program to overcome the problem and make SMEs in Indonesia grade up. The program uses digital literacy in developing SMEs businesses. This research is to find out the extent to which the program has been running, its implementation, including obstacles in efforts to help SMEs use digital technology to grade.

\section{LITERATURE REVIEW}

Development of SMES based on the application of digital technology will be accompanied by the ability to use such technology to access, manage, integrate, analyze and evaluate information, construct new knowledge, and create and communicate with others. The development of SMES in the context of this should be put as efforts to increase the productivity of the public sector (Widyastuti, Nuswantoro, \& Sidhi, 2016). Widyastuti, Nuswantoro, \& Sidhi (2016) argues that the integration of management of quality, development of human resources, adaptation of technology, strategic partnerships and measure performance of the organization, will result in increased productivity of the public sector if synergized with capital, labor and energy. Given the current world, including Indonesia, entered in the era of information-based technology by Alvin Toffer is defined as the third wave of the human being (Toffler, 1984).

Then the point of the press increase in quality or to the development of SMES is put on the adaptation of technology. Digitizing organization is only possible when the members of the organization is already digital literacy, which is a condition when the technology has become part of everyday life. However, if this condition is not achieved, then to develop SME-based digital necessary digital literacy. Adams \& Hamm (2001) says that literacy is the ability to read, write, speak, hear, think and see. Kress (2003) also say that literacy is used when creating messages with letters with the purpose of recording the message.

Digital literacy, according to James Potter, is as follows:

"A set of perspectives that we actively expose ourselves to the media to interpret the meaning of the messages we encounter. We build our perspectives from knowledge structures. To build our knowledge structures, we need tools and raw material. These tools are our skills. The raw material is information from the media and the real world. Active use means that we are aware of the messages and are consciously interacting with them (Potter, 2005: 22)."

Digital literacy, according to Potter is the interest, attitude and ability of individuals to use digital technology and communication tools to access, manage, integrate, analyze and evaluate information, construct new knowledge, create and communicate with others in order to participate effectively in society.

In the conception of Potter's effort to meliterasi community-based digital means not only introducing digital media, but also synergize with the activities of day-today (including the organization) that lead to increased productivity. The term digital literacy own start popular around the year 2005 (Davis \& Shaw, 2011). Digital literacy means the ability to get in touch with information hipertekstual in the sense of reading not a sequential computer assisted. The term digital literacy once used in the 1980 os (Davis \& Shaw, 2011), when computing technology began to be used to support the day to day life. Gilster (1997) later expanded the concept of digital literacy as the ability to understand and use information from a variety of digital resources for the benefit of 
the development of self and organization. According to Yanti \& Yusnaini (2018), digital literacy can be defined as the ability and skills necessary to access the digital technology available and to engage in practices and digital culture. The end result of the movement of digital literacy itself is a reduced crime digital, growing the digital economy, knowledge, digital skills, and digital governance, as well as the childbirth practices of use of information and communication technology refers to three principles, namely: the principle of security, economic principles, and the principles of socio-cultural, (Yanti \& Yusnaini, 2018).

\section{Micro, Small, and Medium enterprises (SMES) Go Online}

In general SMES Go Online is an effort of thegovernmenttoencourageSMEStoahigher class. In a narrow sense can be regarded as businesses that successfully develop aspects of the business activities undertaken, with the shown by the indicator-the indicator is objective and measurable, for example aspects of production, marketing, financing, institutional and Human resources. As for in the broad sense that businesses that already have the characteristics of the entrepreneur is characterized by vigor, attitude, behavior, and ability to handle business and/or activity that leads to the effort to find, create, apply ways of working, technology, and new products to increase efficiency in order to provide better service and or obtain greater profits. All businesses have the same potential to up grade to a higher category. Micro can be a small business, small business and become medium-sized businesses, medium-sized businesses become large businesses (Setiawan, Indiastuti, Indrawati, \& Effendi, 2016).

\section{METHODS}

This research was conducted by describing the primary and secondary data obtained through ethnographic digital (online), which then performed the qualitative analysis. This research uses a qualitative content analysis approach, (Yanti \& Yusnaini, 2018) where the primary data of this study comes from news portals that feature news containing the keyword phrase "UMKM go online" and "digital literacy". Where secondary data is collected from public, private, and/or civil society organization publications related to the Go Online SMEs program. Secondary data forms can be scientific journals, reports or official news agencies.

Primary data in this study came from the web in the form of news (news) containing the keyword phrase "SMEs digital literacy". In a search on Google on the 7th August 3019, only content that matched the keywords was analyzed. There are three stages in the analysis where the first stage is coding data. At this stage, the researcher reads the narrative of the text with the aim of coding the data into code. This coding process refers to the focus of research and produces certain categories that are ready to be further analyzed. In the second stage, researchers will present the data that has been processed followed by discussing research findings. The unit of analysis of this research is the institution, organization or institution, (Yanti \& Yusnaini, 2018).

\section{RESULTS AND DISCUSSION}

\section{Digital literacy SMES}

The government in this case Ministry of Cooperatives and SMES and the Ministry of Communications and Information technology initiated the program "Movement SMES Go Online". The Program was launched in the year 2017 and keep running until 2019. For the year 2019, the government launched a movement of 100,00o SMES Go Online simultaneously in 30 cities/districts in Indonesia and to make Indonesia as the Digital Energy of Asia. The government, in this case the Ministry of Cooperatives and UKM with the Ministry of Communications and information technology, is committed to mengonlinekan 8 million SMES until year 2020. This commitment shows the concern of the government in promoting SMES as one of the backbone of the economy of Indonesia (Kominfo.go.id, 2019). 


\section{SMES Ride the Class As a Special Terms}

SMES can, of course requires a large effort. According to Sukmono (2019), SME Up the Class at first is a special terms that becomes the vibration of the spirit for SMES to improve capacity and competence of the business to be able to grow into a business that is productive and competitive. The growth of this business, I categorize in the 5 stages of SMES Up Classes or Growth Stages of the Entrepreneur, namely:

\section{a. Motivating}

What distinguishes a person called as an entrepreneurliesinthespiritand thecharacter. If someone has the motivation and desire to become a businessman/entrepreneur he was on the level of entrepreneurship earliest. So he must be accompanied in order to pass the class, take a step brave, start as a business.

\section{b. Starting}

Starting a business means to start the calculation. The risk is successful or failed. Many SMES do not know what should be done in stages Starting this, so spend the time and capital only to open a business and strive so as not to close the lid. Should be at this stage, the SMES focus to strengthen the four Pillars of the Business $\left({ }_{4} \mathrm{P}\right)$, and if it is sturdy new up grade to the next level.

\section{c. Stabilizing}

The business in this phase, it means they have already found the core of the business and the 4 pillars of the business has been robust. Then the next task is how to create a Business System. The larger the capacity of a business carried on, more and more employees, the many affairs he could not do alone then it's a marker of the business requires systems to control. The focus in this phase is to make the business auto pilot before boarding the class on the next target.

\section{d. Spreading}

This phase is the part for businesses who are already ready to up grade from the phase of stabilizing. That is the system the business is already organized, competent human resources, as well as to have the direction and policy development that are measurable and systematic. Model development can be manifold, such as the opening of branches, franchises, partnerships, market diversification, and so on. If you're here, then the entrepreneur has a target grade of the last, namely to the utilization of the results of his hard work in accordance with the vision and purpose of his life.

\section{e. Freedom}

Free what the be the highest purpose for Your business. Because of freedom, then there are no provisions or restrictions that govern our business should be how, unless we own that determines, our own limits will be used for what are the results of the efforts of our work to build a business stage by stage. Freedom is the highest grade for entrepreneurs in the spirit of the Movement of SMES to a higher Class.

\section{SMES Ride the Class As a Movement}

Inthedevelopmentoftheimplementation milestone RE2020, perceived very well that the milestone of both enterprises (SMES Rose Class) should be done in convergence with the milestone third (Market Siding). It takes alignments of the market to support SMES Up Class, on the contrary SMES must up grade to the market a side. It was always like that, first the egg or the chicken. Then the Movement of SMES Rose Class and the Market Siding in parallel campaigned to all the parties in the various forums, various communities, and various occasions.

At this stage, SMES Rose Class is a movement that has the goal to campaign in the environment of SMES and stakeholders about the importance of mindset and skills in managing businesses take into account carefully the process of the growth of the business measured to achieve the sustainability of the business. The size of the growth of SMES called SME Up Grade located on three of the five stages of SMES Rose Class, namely the stage of starting, the phase stabilizing and phase spreading. 


\section{SMES Ride the Class As the Curriculum}

As a curriculum, SMES Rose Class is the unity model approach (indicators and how) required SMES and stakeholders to realize the growth of character, competence, and capacity of SMES to increase the productivity and competitiveness of SMES in Indonesia are immeasurable in the development of the global ecosystem. In other words, SMES Rose Class is the level of measure that indicates the growth of SMES in a certain period that includes the 3 main indicators, namely Character, Competence, and Capacity.

\section{Digital literacy For SMES}

The one that should be done UMKM up grade is to use digital literacy. Quoted from Beritasatu.com (2018), there are currently 62,92 million business units or to $99.92 \%$ of the total business units in Indonesia are SMES contribution to GDP reached 6o\% and the absorption of labor 116,73 million people or $97,02 \%$ of the total labor force that is working. Citing data Delloite Access Economics, shows more than a third of SMES in Indonesia (36\%) still offline, another onethird $(37 \%)$ only have online capabilities which is very fundamental such as a computer or broadband access. Only a small percentage $(18 \%)$ who have the capabilities of the online medium (using the web or social media) and less than one-tenth $(9 \%)$ is the online business advanced e-commerce capabilities.

Certainly not easy to suddenly make SMES use digital literacy to develop its business. At least needed socialization and training in SMES related to the use of digital technology. Starting from the most simple with the use of social media, to the application of the online business actually. That's what the so challenge the government in order to make the program successful Movement SMES Go Online where the program is the practice of digital literacy of SMES. Data from the McKinsey Global Institute showed only $5 \%$ of SMES that have been able to transact online. In fact, the involvement of SMES in digital can increase economic growth by $2 \%$. In fact, predicted to have income growth of between $23-80 \%$ if skilled take advantage of digital technology.

\section{The Implementation Of The Programme}

Movement SMES Go Online will help SMESgettheopportunitiesforthedistribution of People's Business Credit (KUR), the largest in $1 \times 24$ hours, the Incorporation of new classrooms, the transformation of financial inclusion, as well as the opportunity to make Taxpayer Registration Number (NPWP) simultaneously to all SMES that will online. The SMES will also be guided from the online process to the management and online promotion. The promotion process itself will be assisted starting from the photo shoot of the product, product description, price, and also got the domain .id at once the hosting for free. The products of SMES that have been registered will then be promoted and placed on the marketplace great delivery, Blibli.com, Elevania, etc.

The government with its efforts to support SMES have been doing some steps, such as the financing of alignments to SMES by lowering the People's Business Credit to $9 \%$, as well as established Institutions Financing Revolving Fund (LPDB). Some of the programs that are already running, among others, the counter of e-commerce, developing consumer protection regulations, so that the data of internet users so as not abused the other party. It also made the construction of infrastructure of 5,00o BTS, with the purpose of the entire territory of Indonesia can access the internet. The construction of the logistics network and security of internet users. Currently SMES use the services of the internet is approaching 4 million, while in 2020 ditargetken be 8 million SMES.

To grow the number of SMES who are surfing in the virtual world, ministry of cooperative and SMES and the Ministry of Communications and Information technology together with the actors of e-commerce initiated a program titled 8 Million SMES Go Online. The government hopes to accelerate the transformation of SMES in Indonesia toward digital. SMES should be the main player of the development of digital economy in Indonesia. Collaboration between government and e-commerce will 
continue and be able to realize a shared vision to make Indonesia as the Digital Energy of Asia in 2020 that target the growth of e-Commerce transactions amounted to USD1zo billion. Movement SMES Go Online held simultaneously in 13 cities of Medan, Jambi, Palembang, Bekasi, Bogor, Balikpapan, Denpasar, Semarang, South Tangerang, Bandung Barat, Purwakarta, Sidoarjo and Surabaya (CNNIndonesia.com, 2017).

\section{Digital payments For SMES}

The increasingly widespread trend of electronic money and digital payments today, make SMES inevitably have to adjust with advances in technology. The government, through the the Ministry of Communications and Information technology also encourage the SMES in Indonesia to digital literacy and using digital payment system. The government is targeting 8 million SMES in the country are already using the digital services by 2020 . According to The Minister, the payment systems that exist today must have been in favor of electronic money, not only businesses only large, but also small entrepreneurs or SMES. The government Program to create a cashless society and financial inclusion can be achieved with the penetration of e-money to the community running smoothly. Some companies in Indonesia expressed his commitment to support non-cash movements launched by the government. For example, two transport companies online Gojek and Grab, which says it wants to support a cashless society in Indonesia through the features of the payment of the respective digital Gopay and GrabPay.

\section{Barriers}

Program SMES Go Online is very good indeed. But, practice in the field is very likely not as good as the program. There are constraints faced by the SMES who are already accustomed to doing marketing in the conventional manner. One of the problems is the factor of human resources. According to Sukmono (2019), despite having a pretty good prospect and potential contribution is large, the process of digitalization of SMES in Indonesia still face a variety of problems at the grassroots level. The evolution of SMES in Indonesia toward digital marketing today still face a variety of problems. Research conducted by Delloite Access Economics mentions that $36 \%$ of SMES in Indonesia are still struggling with conventional marketing. Whereas, $37 \%$ of SMES only has the capacity of online marketing that are fundamental such as computer access and broadband. The rest, amounting to $18 \%$ of SMES have a capacity of the online medium because it can use the website and social media. Only $9 \%$ have the capacity of digital marketing that can be categorized as advanced.

The conditions of the limitations of SMES in Indonesia is entering the digital market is also reinforced by the study (Rahayu \& Day, 2017: 147) mention that the characteristics of SMES in Indonesia is still very little to develop digital marketing that is networked and using sophisticated technology. This can be seen from the SMES that still use static site amounted to $32.5 \%$, the site interactive by $25 \%$, and has not been involved in the digital percentage at $7.2 \%$ of SMES.

Problems by SMES towards the digital market also we can see from the achievement that is visible from the implementation of the program e-smart that was launched by the government. Until the middle of 2018, the total turnover of SMES through e-smart only Rp.6oo million. Some of the products sold through the online market such as SMES engaged in the food sector by $38 \%$ and which is engaged in the metal industry accounted for a percentage of $20 \%$. But, the turnover of transactions of SMES online is still said to be very minimum and need a lot of evaluation. The biggest obstacle that SMES face is the lack of quality of the marketed products so not sold in the market.

\section{The Best Scheme}

Of the various problems faced by SMES in the above, the government technical ministries such as the ministry of cooperative and SME as well as Communications and local government should begin to formulate the best scheme to eliminate the barriers 
of SMES in entering the networking of digital marketing. Although not close the possibility of competition among SMES was fierce, with the support of the government and the innovation that is done independently, small and medium enterprises will be able to compete in the digital market (Savrul, Incekara, \& Sener, 2014). One of the advantages obtained when SMES plunge in the market of e-commerce is the image of the company increased and can bring up the networking marketing with more quick (Jahanshahi, Skogestad, \& Grøtli, 2013). With the meaning that digital literacy is a concept that leads to mediation between the technology with the audience or user to practice digital technology in a productive manner, then the movement of digital literacy was designed and organized in various regions. The purpose of digital literacy is basically the same, although its activity varies, (Kurnia \& Astuti, 2017).

To complete a wide variety of issues, the government should formulate some effective steps to encourage SMES in Indonesia market their products online. The first step government should do is as the maximum utilization of broadband has been installed in 400 districts and 114 area. The utilization of infrastrukutr technology this also should be coupled with efforts to improve the capacity of SMES in the regions through the collaboration built between the technical ministries in the center with the department in the area as well as the district administration or the city (Hejazziey, 2009)). The culture of digital literacy should not focus too much on the skill of the use of technology, but in the acquisition and mastery of the process skills of information and communication technology (Vélez, Olivencia, \& Zuazua, 2017).

The next step that can be taken by the government is to expand access to finance for SMES as a capital to increase capacity. Agreed with the solution offered by Delloite Access Economics, the government needs to improve the ease of access to low-interest loans to the SMES. Granting access to easy credit must also be coupled with the determination of tax for SMES which market their products digitally. The government should equalize income tax SMES online with based conventional of $0.5 \%$. If this scheme can be run optimally, SMES Go Online to contribute to the economy are quite significant.

For SMES themselves, using digital literacy in a simple without having to spend a lot of costs can be done, namely by using social media. SMES can take advantage of the many group buy on Facebook and other social media such as Instagram. It is the initial stage towards digital literacy in SMES. To really harness the digital technology of course there are still further stages are carried out until finally completely practice a online business advanced.

\section{CONCLUSION}

Based on research, more than one third of SMEs in Indonesia (36\%) are still offline, another third $(37 \%)$ only have very basic online capabilities such as computers or broadband access. Only a small proportion $(18 \%)$ have medium online capabilities (using the web or social media) and less than one tenth $(9 \%)$ are advanced online businesses with e-commerce capabilities. In addition, only $5 \%$ of SMEs are able to transact online. In fact, the involvement of SMEs digitally can increase economic growth by $2 \%$. The Go Online UMKM movement together with e-commerce actors has started in 2017 and continues to this day. The government is targeting as many as 8 million SMEs Go Online to accelerate SMEs to grade. Through this cooperation, the government hopes to accelerate the transformation of SMEs in Indonesia towards digital so that they can advance faster. The study recommended the importance of the government conducting intensive socialization of the Go Online UMKM Movement. In fact, it must also be at the level of assistance for SMEs. SMEs must be the main players of the development of the digital economy in Indonesia. Collaboration between government and e-commerce is carried out continuously to make Indonesia the Digital Energy of Asia by 2020. 


\section{REFERENCES}

Adams, D. M., \& Hamm, M. (2001). Literacy in a multimedia age. ChristopherGordon Pub.

Alamsyah, \& Purnama, D.H. (2017). Digital literacy among Sriwijaya University lecturers. Informasi. 47(2), 243-254.

Beritasatu.com. (2018). Mayoritas UMKM belum dapatkan manfaat dari teknologi digital. https://www.beritasatu.com/ ekonomi/500255/mayoritas-umkmbelum-dapatkan-manfaat-dariteknologi-digital, accessed 24 July 2019.

Bisnis.com. (2017). Literasi digital UMKM perlu ditingkatkan. https://ekonomi. bisnis.com/read/20170518/87/655035/ litera si-digital-u m km-perluditingkatkan, accessed 24 Juli 2019.

CNNIndonesia.com. (2017). Kemenkop UKM, 37,9 juta UMKM sudah go online. (2017). https://www.cnnindonesia.com/ ekonomi/20171115161037-78-255819/ kemenkop-ukm-379-juta-umkmsudah-go-online, accessed 25 July 2019.

Davis, C.H., \& Shaw, D. (2011). Introduction to information science and technology. New York: Medford Information Today.

Gilster, P. (1997). Digital literacy. New York: Wiley.

Hafiluddin, M. R., Suryadi, S., \& Saleh, C. (2014). Strategi pemberdayaan usaha mikro kecil dan menengah (UMKM) berbasis "community based economic development"(studi pada pelaku UMKM di kecamatan Sukodono kabupaten Sidoarjo). WACANA, Jurnal Sosial dan Humaniora, 17(2), 68-77.

Hejazziey, D. (2009). Pemberdayaan koperasi, usaha mikro, kecil dan menengah (UMKM) melalui lembaga keuangan syariah (LKS) untuk mengentaskan kemiskinan dan pengurangan pengangguran. Al-Iqtishad: Jurnal Ilmu Ekonomi Syariah, 1(1). 32-52.

Jahanshahi, E., Skogestad, S., \& Grøtli, E. I. (2013). Nonlinear model-based control of two-phase flow in risers by feedback linearization.

Jordana, T.A, \& Suwarto, D.H. (2017). Pemetaan gerakan literasi digital di lingkup Universitas Negeri Yogyakarta. Informasi, 47(2), 167-180.

Kominfo.go.id. (2019). UMKM go online, upaya wujudkan visi "digital energy of Asia”. https://www.kominfo.go.id/ content/detail/9514/umkm-go-onlineupaya-wujudkan-visi-digital-energyof-asia/o/berita_satker, accessed 7 August 2019.

Kress, G. (2003). Literacy in the new media age. New York: Routledge.

Kurnia, N., \& Astuti, S.I. (2017). Peta gerakan literasi digital di Indonesia: Studi tentang pelaku, ragam kegiatan, kelompok sasaran dan mitra. Informasi. 47(2), 149-166.

Potter, J.W. (2005). Media Literacy. London: Sage Publication.

Rahayu, R., \& Day, J. (2017). E-commerce adoption by SMEs in developing countries: evidence from Indonesia. Eurasian Business Review, 7(1), 25-41.

Savrul, M., Incekara, A., \& Sener, S. (2014). The potential of e-commerce for SMEs in a globalizing business environment. Procedia-Social and Behavioral Sciences, 150, 35-45.

Setiawan, M., Indiastuti, R., Indrawati, D., \& Effendi, N. (2016). Technical efficiency and environmental factors of the micro, small, and medium enterprises in Bandung city: a slack-based approach. International Journal of Globalisation and Small Business, 8(1), 1-17.

Sukmono, C.J. (2019). Definisi UMKM naik kelas, indikator, dan model pendampingannya, https:// umkmjogja.id, accessed 29 July 2019.

Supriyanto, S. (2006). Pemberdayaan usaha mikro, kecil dan menengah (UMKM) sebagai salah satu upaya 
penanggulangan kemiskinan. Jurnal Ekonomi dan Pendidikan, 3(1), 1-16.

Toffler, A. (1984). The third wave: The classic study of tomorrow. New York: Bantam.

Vélez, A. P., Olivencia, J. J. L., \& Zuazua, I. I. (2017). The role of adults in children digital literacy. Procedia-Social and Behavioral Sciences, 237, 887-892.

Wicaksono, R. (2018). Digitalisasi UMKM roda baru ekonomi. Kompasiana. com. https://www.kompasiana.com/ riski_w/5bd1744d6ddcae1876747762/ digitalisasi-umkm-roda-baruekonomi, accessed 24 Juli 2019.

Widyastuti, D. A. R., Nuswantoro, R., \& Sidhi, T. A. P. (2016). Literasi digital pada perempuan pelaku usaha produktif di Daerah Istimewa Yogyakarta. Jurnal Aspikom, 3(1), 1-15.
Yanti, M. \& Yusnaini, Y. (2018). The narration of digital literacy movement in Indonesia. Informasi, 48(2), 243-255. 